\title{
Religious Coaching and Mental Health: Case Study at MAN Indragiri Hilir
}

\author{
Marwan 1,a, Raja Rahima Munawarah Raja Ahmad11,b, Zaitun ${ }^{1, c}$, Nurhayati Zein ${ }^{1, d}$, Kasmiati $^{1, e}$, and Musa Thahir ${ }^{*}$ \\ 1 Department of Islamic Education, Faculty of Tarbiyah and Teacher Training, Universitas Islam Negeri Sultan Syarif Kasim Riau, 28293, Indonesia \\ 2Department of Mathematics Education, Faculty of Teacher Training and Education, Universitas Islam Negeri Sultan Syarif Kasim Riau, 28293, Indonesia \\ a marwan@uin-suska.ac.id; b raja.rahima@uin-suska.ac.id; c zaitun@uin-suska.ac.id; d nurhayati.zein@uin-suska.ac.id; e kasmiati@uin-suska.ac.id \\ *musa.thahir@uin-suska.ac.id \\ Whatsapp Number [085263678409]
}

How to Cite: Marwan, M., Ahmadi, R., R., M., R., Zaitun, Z., Zein, N., Kasmiati, K., Thahir, M. (2020). Religious Coaching and Mental Health: Case Study at MAN Indragiri Hilir. International Journal for Educational and Vocational Studies, 2(8), 708-713. DOI: https://doi.org/10.29103/ijevs.v2i8.2645

\section{ARTICLE HISTORY}

Received: 1 July 2020

Revised: 11 July 2020

Accepted: 26 July 2020

\section{KEYWORDS}

Religious Coaching; Mental Health;

Religious;

\section{ABSTRACT}

This research is motivated by the mental inadequacies of students who can hinder the goals of education and teaching in the school environment. Therefore, mental health guidance is needed through religious formation. Based on these phenomena, this study aims: 1) to find out the efforts made by teachers in developing religious and mental health of students in MAN Indragiri Hilir; and 2) to analyze the presence or absence of the influence of religious guidance on the mental health of students in MAN Indragiri Hilir. The research method used was a quantitative study conducted on 56 students. Data collected through observation, interviews and questionnaires. After the data is collected completely, a data analysis is done using a simple linear regression test with the help of SPSS version 23.00 for Windows. The results obtained from this study include: 1) religious guidance conducted by teachers in mentally developing students, including: habituation of Dhuha prayer, Dhuhr prayer in congregation, reading Asmaul Husna and giving Jariyah every Friday in each class. While activities outside of effective learning hours include social service and apostolic assembly; and 2) there is an influence of religious guidance on the mental health of students by $53.7 \%$ on mental health in MAN 2 Indragiri Hilir.

This is an open access article under the CC-BY-SA license.

\section{INTRODUCTION}

One of the main problems that has become the problem of the Indonesian state to date is about development, especially mental development. That is because the mental dimension is the control of every movement, attitude and action of humanity. If someone's mental experience problems, then all efforts and actions aimed at the development of all fields will not necessarily bring the expected results, namely creating a happy and blessed life of God Almighty. Religion as a mental control tool for someone and also functions as a builder of one's personality, is an inseparable element in the process of integrity of a personality. Religion can have a significant impact on human life, including mental health (Abdul Hamid, 2017). Furthermore, the practice of religious values greatly influences mental health (Ulin Nihaya, 2016). Thus, it can be understood that a person who is mentally healthy will always feel safe and happy in any condition, he will also do introspection on everything he does so that he will be able to control and control himself.

In today's modern era, many changes in various aspects of life, ranging from economic, educational, cultural and cultural aspects, are developing more rapidly
Not infrequently, it can make some people who are less able to adapt to the progress of the times, then their mental health is disturbed. Based on the results of research conducted by the Republic of Indonesia Research and Development Agency shows that there is an indication of a decline in mental health in the community in several regions of the Republic of Indonesia (Reza, 2016). According to el-Quussiy that mental health is a perfect harmony or integration between various functions of the soul, accompanied by the ability to deal with mild mental tremors, which are common in people, as well as being able to positively feel happiness (Reza, 2016). According to Daradjat that mental health is the realization of a true harmony between mental functions and the creation of self-adjustment between humans and themselves and their environment, based on faith and piety and aims to achieve a meaningful and happy life in the world and the hereafter (Ade Masturi, 2019). Mental health is a mental state or psychological state that shows a person's ability to make adjustments or problem solving to problems that exist within oneself (internal) and problems that exist in the environment outside of 
themselves (external) (Fattah Hanurawan, 2012). Furthermore, mental or mental health is vital for humans as well as physical or physical health in general (Adisty Wismani Putri, Budhi Wibhawa, 2015). With a person's mental health or mental health, other aspects of life in him will work more optimally. Mental health refers to the way of thinking, feeling and acting of individuals who are efficient and effective in dealing with life challenges and life stress.

Next Jahoda said mental health is not only limited to the absence of a person from psychiatric disorders and illness. However, mentally healthy people have the following main characteristics: 1) a good personality attitude towards oneself in the sense of being able to get to know yourself well; 2) good growth, development and self-realization; 3) self-integration which includes mental balance, unity of view, and resistance to the pressures that occur; 4) self-autonomy which includes elements regulating behavior from within or free behaviors; 5) perception of reality, free from deviations of needs, and have empathy and social sensitivity; 6) ability to master the environment and integrate (Reza, 2016). From several understandings of mental health, the author focuses the opinion of Daradjat that reveals mental health is the realization of a truly harmony between mental functions and the creation of self-adjustment between humans and themselves and their environment, based on faith and piety, and aims to achieve life meaningful and happy in the world and the hereafter.

Al-Ghazali establishes mental health indicators based on all aspects of human life in the form of the habl min of Allah, habl min al-nas, and habl min al-alam. The indicators of mental health include: 1) a continuous balance between physical and spiritual in human life; 2) having the nobility of morals and unity of the soul, or having the quality of faith and piety living; 3) has a consensus to God (Reza, 2016). Furthermore, according to Az-Zahrani indications for mental health include: 1) the spirituality side; 2) social side; 3) biological side (Massuhartono, 2018). According to Faraj mental health indicators include: 1) feeling safe and secure; 2) if you accept yourself; 3) able to control themselves proportionally when required to do spontaneous things and have the ability to start something; 4) able to foster active interaction and satisfy other parties; 5) have a realistic view of living life and can deal with various problems naturally (Iredho Fani Reza, 2015). According to Hasan Langgulung, mental health can be concluded as a noble character (Firmasyah, 2017). Therefore, mental health is defined as a state of the soul that causes to feel willing and sincere and at ease, when he is carrying out noble morals. According to the Islamic view, mentally healthy people are people who behave, think, and feel their mental condition, in accordance with Islamic teachings. Thus it can be understood that a mentally healthy person is a person in whom there is integration between behavior, feelings, thoughts and soul diversity.

In this case, school is one of the educational environments that has a major influence on the mental development of students or adolescents. In addition to educating intelligence and skills, schools also strive to provide guidance that is positive for their students. Schools play an important role in the formation of children's personal education, as well as the formation of the foundations of education that will become a provision of life and struggle in the future and reflect the good and bad of society to come (Lina Hadiawati, 2008). Furthermore, the development of religious culture in schools in the mental development of students can be realized through various religious activities as a vehicle in an effort to create and develop a religious culture in schools (Maryamah, 2013). Therefore, as a religious educator in school, in any way he should try to foster children's religion, so that children will become firm in their stand and belief in Allah SWT.

MA/MAN students in general have psychologically entered adolescence. Hurlock states that adolescence is also called a period of change, the level of change in attitudes and behavior during adolescence is parallel to physical changes (Kenny Dewi Fhadila, 2017). At that time, a teenager may feel at the top of the world at one time but feel worthless at the next time. Because their souls are unstable, teenagers often behave and behave in ways that are not in accordance with eastern ethics, religion or customs. Mental health disorders in adolescents today need attention together because mental disorders contribute $23 \%$ of the world mental health burden (Anita Novianty, 2017). Based on research results, the incident of cutting a hand at one of the state junior high schools in Pekanbaru involving as many as 56 students who scratched their hands with a needle, broken glass, and a small knife (Layla Takhfa Lubis, Laras Sati, Naura Najla Adhinda, Hera Yulianirta, 2019); dan students of SMAN 11 Surabaya experience mental disorders in the form of excessive anxiety, anxiety and fear (Edi Kuswadi, 2019). Mental health phenomenon also occurs in MAN Indragiri Hilir which is characterized by symptoms: 1) anxiety facing the exam; 2) frustration related to learning material that is difficult for students to understand; 3) depression caused by failure to achieve the national final examination score standards.

The various problems above show that students as individuals experience various obstacles to mental health and need solutions or the right solutions to overcome those obstacles. One of the right solutions can be done by increasing Islamic worship through religious formation. Coaching is the process of deeds, renewals, improvements, efforts, actions, and activities carried out continuously to obtain better results (Lina Hadiawati, 2008). It is true that the task of children's personal coaching at school is not only the task of religious teachers, but the task of teachers in general, in addition to the task of parents. However, the role of religious teachers in this case is crucial. Religious teachers can correct mistakes made. According to Elizabeth that religion is a phenomenon that is so often found everywhere and religion is related to 
human efforts to measure the meaning of the existence of self and the existence of the universe (Lina Hadiawati, 2008). Religious education in educational institutions, however, will have an influence on the formation of religious life in children. However, the size of the aforementioned influence is highly dependent on various factors that can motivate children to understand religious values. Because religious education is essentially a value education. Therefore, religious education is more focused on how to form habits that are in line with religious demands.

Learning habits is the process of forming new habits or improving existing habits. Learning habits, in addition to using commands, role models and special experiences, also use penalties and rewards. The goal is that students obtain new attitudes and habits of action that are more appropriate and positive in the sense of being in harmony with the needs of space and time (contextual). In addition, the precise and positive meanings above are in harmony with prevailing moral norms and values, both religious and traditional and cultural (Moh Ahsanulkhaq, 2019). Every student who has experienced the learning process, his habits will seem to change. According to Burghardt that the habit arises because of the process of shrinking the response tendency by using repetitive stimulation (Nurhayati, 2015). In the learning process, habituation also includes reducing behaviors that are not needed. This is because of this shrinkage / reduction process, a new pattern of behavior that is relatively permanent and automatic emerges. This habit occurs because of habituation procedures such as in classical and operant conditioning.

Religious development is an effort to guide and maintain and develop or perfect religious understanding (Islam) in all aspects, both in terms of creed, worship and moral aspects (Samsurijal, 2019). Religious development is a systematic planned effort in the form of guidance, provision of information, supervision and also control to improve the quality of students, especially in matters of religion in creating mental attitudes and the development of positive potential to form a good diversity in students (Maryamah, 2013). Several studies have shown that religious formation can be carried out in several ways including: morning and evening halaqa, Islamic study activities and mufradat activities (Yunita Latifah, Agus Fakhruddin, 2015); scout activities, duha prayer, tahfidz al Qur'an, and kitabah (Samsurijal, 2019); and religious guidance is carried out through ways, performing five daily prayers on time at the mosque, getting in the habit of thinking and praying, reading the verses of the Koran, practicing the sermon by each student, holding Friday prayers together at the school mosque, and performing ceremonies every Monday which in the ceremony there is a recitation of prayer, as well as commemorating Islamic holidays with events that contain religious values (Haris Munandar, 2018). Based on the results of these studies it can be understood that in caring for mental health through religious formation can be done by providing religious knowledge and experience to students through a variety of things, including through Islamic studies, prayer in congregation, khotmil quran and so on. Guidance and guidance on the implementation of worship is certainly inseparable from the efforts of teachers in fostering the mental health of students to become human beings who believe and fear God.

Based on a theoretical framework and taking into account existing problems, several problems can be identified such as the implementation of worship, academic community debate about the role of religion in human life, and the synergy between religion and mental health. Therefore, this research is focused to see the effect of the implementation of religious guidance on mental health.

\section{MATERIALS AND METHODS}

Survey research methods with a quantitative approach (Cucun Sunaengsih, 2016) became the research method chosen in this study to answer research questions. Quantitative data were taken from 56 students of MAN Indragiri Hilir through observation techniques, and interviews with the aim of obtaining an overview of the implementation of religious coaching conducted by madrasas in fostering students' mentality. In addition to observation and interviews, researchers also conducted a questionnaire to students, which is a guideline used for. The statement outlined in the questionnaire was submitted to the students concerned to obtain and collect information data about the problem under study, in this case the description of the implementation of religious guidance in madrasas. Data obtained through a questionnaire were analyzed descriptively and inferentially, namely a simple linear regression test using SPSS version 23.00 for Windows.

\section{RESULTS AND DISCUSSIONS}

\subsection{Teacher's Efforts in Fostering Religious and Mental Health Students in MAN 2 Indragiri Hilir}

MAN 2 Indragiri Hilir was once a madrasa that was not well known by the community. With hard work and the role of teachers and employees at the school, able to make MAN 2 Indragiri Hilir develop into a school that is full of achievements. This is because education output is the collective result of madrasas, among individuals in school must be the daily habits of madrasas, along with the increase in achievements obtained by MAN 2 Indragiri Hilir from year to year eventually the community becomes more trusting. Dealing with this Sardiman A.M argues that the role of the teacher as a motivator is very important meaning that in order to increase enthusiasm and development of student learning activities (Faulina Sundari, 2017). Teachers are required to be able to stimulate and provide encouragement to dynamic students' potential, foster activity and creativity will occur dynamics in the learning process (Istiqomah, 2018). The 
spirit and hard work of the instructor teacher for religious guidance for students is of course coupled with serious efforts. In their efforts to improve this mental training program, religious teachers act as the core executors of religious programs. In line with the mental development of students, the school is required to be able to plan, implement and evaluate and account for madrasah management honestly to the local community. Accountability can be done through meetings and coordinating meetings with the madrasa council by publicly describing all school issues, especially madrasa issues.

Efforts made by the teacher in mentoring at MAN 2 Indragiri Hilir are holding a variety of positive activities towards mental development of students such as habituation of dhuha prayer, recitation of Al-Qur'an before learning begins, Dzuhur prayer in congregation, reading Asmaul Husna and giving Jariyah (donations) voluntary) every Friday in each class; the cult on Friday morning; while activities outside of effective learning hours in the form of weekly wirid carried out in the large mosque of the district, which was attended by students and the local community by inviting religious teachers in accordance with the field of religious studies. The results of this study are in line with what was done at MA Surban Pacet Mojokerto that the efforts of the head of madrasa in fostering religious culture is to get used to and oblige to read Asma'ul Husna before the start of learning activities, get used to reading the Yasin letter on Friday, and worshipers dhuha later Zuhr every day (Muhammad Nur Hakim, 2018); (Aisyahnur Nasution, 2019); and (Iwan Setiawan, Andewi Suhartini, 2020). Based on this research, it can be understood that religious formation is closely related to religious culture. In fostering this religious culture with the habit of reading the reading of the Koran, the head of the madrasa strives to provide understanding and planting to students in carrying out this religious culture, as well as training students to familiarize dhuha and dhuhur prayers in congregation, reading yasin and wirid.

This habit of religious formation is one of the extracurricular activities at MAN 2 Indragiri Hilir. This activity aims to increase and broaden students' knowledge about various fields or discussions of Islamic religious education. From the results of observations, that this religious coaching activity is applied to all students. This religious formation has an impact on the mental health of students. For example, students are able to apply a number of attitudes or morals towards fellow human beings, namely the sense of brotherhood that is applied through silaturrahmi, courtesy to everyone, please help be honest, both words and deeds, as well as discipline increase from year to year (Jumhuri, 2016). The implementation of religious development programs in MAN 2 Indragiri Hilir can be interpreted, that it is very appropriate in order to solve the problems of students, which are less productive in utilizing time and also for religious guidance of students, both towards Allah. and towards fellow human beings.

According to Hafid Abdurrahman that the issue of religious formation is indeed not a problem that can be disputed, which ensures there are no differences of opinion, so it is not appropriate for one to follow the mujtahid and leave the other mujtahid (Sariah, 2015). In an effort to optimize religious guidance through extracurricular activities, it is carried out by integrating every activity in the values of Islamic education, such as the values of discipline, mutual respect, and a sense of responsibility both towards God, and towards fellow human beings (Kamra, 2019). In every activity religious formation is emphasized on habituation by carrying out strict supervision through the control card given by the coach to the students. In addition to optimize coaching, cooperation is carried out with the guardians of students so that they can understand and help carry out coaching at home.

Religious coaching is applied in the context of accustoming students to practice every teaching of Islam which consists of three main aspects, namely: Faith (faith), Islam (worship), and Ihsan (morals). These three aspects are implemented in every extracurricular activity such as moral guidance in scouting activities, duha prayer every day before learning begins, tahfidzul qur'an activities and religious insights as well as mental guidance in lecturing on biblical activities. Ideally, the three dimensions of diversity cannot be separated from one another.

\subsection{Effect of Religious Development on Mental Health of Students}

The results showed that there was an influence of religious guidance on the mental health of students in MAN 2 Indragiri Hilir. This is evidenced by the significance value obtained less than $0.05(0,000<0.05)$ and a regression coefficient value of 0.938 which indicates an increase in mental health variables of 0.938 based on changes in the variable of religious formation. Religious guidance has an effect of $53.7 \%$ on the mental health of MAN 2 Indragiri Hilir students. The rest is influenced by other variables outside of religious formation. The results of this study are strengthened by previous research which says that there is an effect of an observance of worship on mental health of UIN Walisongo Semarang students (Dawam Mahfud, Mahmudah, 2015). Furthermore, there is a relationship between religiosity and mental health (Ghozali Rusyid Affandi, 2011). Based on the results of this study it can be understood that the more the religious training instincts are carried out to students, the higher the mental health, conversely the lower the religious guidance done to students, the lower the mental health.

The influence of religious coaching on mental health is in line with what was stated by Sundari that by surrendering to Allah SWT will undoubtedly get peace, all the pain or unrest is left to Allah SWT because all things are part of His destiny (Ghozali Rusyid Affandi, 2011). Such beliefs and beliefs will make a person more peaceful, accepting his life and experiencing harmony of the soul. 
Harmony of the soul is related to its ability to use positive self-defense mechanisms, free from feelings of doubt in making decisions, avoiding anxiety about the future and there is no conflict within (Tamama Rafiqah, 2016). Psychological conditions related to mental health can be obtained if an adherent of the teachings of Islam has a strong belief in Islamic values. The existence of a strong belief and internalization of Islamic values in the life of a Muslim will be able to make it not easy to experience frustration, not nervous about the future, able to survive in the face of a problem and a feeling of calm and calm. The calm and serenity is a manifestation of mental health (Zulkarnain, 2019). Mental health has been recognized as contributing to the development of religious, cultural and social community. This is because humans can not be separated from aspects of mental health, because every human being has his style and characteristics in developing his personal spirituality. Not everyone has all the criteria to be called a person who has a healthy mentality because everyone may have certain traits that are characterized as mentally unhealthy. By including aspects of religion which in this case is obedience to worship God, mental health plays a role in all aspects of human life. Likewise, religion is one of the psychic human needs that needs to be fulfilled by everyone who longs for peace and happiness.

Based on the description, it can be understood that mental health is the fruit of the observance of worship of his religion. Because physical and psychological conditions are a unity that must be maintained in harmony, healthy mental people will not experience shock, mental disorder, frustration, or other mental illnesses. In other words, people who have excellent mental health also have balanced intelligence both intellectually, emotionally, and spiritually to achieve happiness in life.

\section{CONCLUSION}

Based on the discussion that has been carried out along with the analysis, the writer can conclude as follows: 1 ) The teacher coach at MAN 2 Indragiri Hilir has held various positive activities towards the mental development of students. This is evidenced by the activities carried out at effective hours of study such as habituation of Duha prayer, recitation of the Qur'an before learning begins, Dzuhur prayer in congregation, reading Asmaul Husna and giving Jariyah (voluntary contributions) every Friday in each class; the cult on Friday morning; whereas activities outside of effective study hours in the form of weekly wirid are carried out in the large subdistrict mosques which are attended by students and the local community by inviting clerics who are appropriate in the field of religious studies; and 2) there is an influence of religious guidance on the mental health of MAN 2 Indragiri Hilir students by $53.7 \%$. The higher the influence of religious guidance, the higher the mental health of MAN 2 Indragiri Hilir students. Conversely, the lower the influence of religious guidance, the lower the mental health of MAN 2 Indragiri Hilir students. Religious coaching is closely related to observance of worship, which is very influential on the mental health of students. Religious environment and good personality will be in harmony with mental health obtained. Therefore, researchers advise MAN 2 Indragiri Hilir to add and provide supporting facilities to increase the portion of spirituality in the madrasa environment because religious facilities such as prayer rooms, ablution places are still very limited and provide strict moral sanctions for students who violate moral values and morals.

\section{REFERENCES}

Abdul Hamid. (2017). Agama dan Kesehatan Mental Dalam Perspektif Psikologi Agama. Jurnal Kesehatan Tadulako, 3(1), 1-14.

Ade Masturi. (2019). Kecerdasan Komunikasi dan Kesehatan Mental. Dakwah: Jurnal Kajian Dakwah Dan Kemasyarakatan, 22(2), 107-122. https://doi.org/10.15408/dakwah.v22i2.12063

Adisty Wismani Putri, Budhi Wibhawa, \& A. S. G. (2015). Kesehatan Mental Masyarakat Indonesia (Pengetahuan, Dan Keterbukaan Masyarakat Terhadap Gangguan Kesehatan Mental). Prosiding Penelitian Dan Pengabdian Kepada Masyarakat, 2(2), 252-258. https://doi.org/10.24198/jppm.v2i2.13535

Aisyahnur Nasution. (2019). Metode Pembiasaan Dalam Pembinaan Shalat Berjamaah dan Implikasinya terhadap Penanaman Budaya Beragama Siswa SMP Negeri 2 Kabawetan. Al-Bahtsu, 4(1), 11-23.

Anita Novianty, M. N. R. H. (2017). Literasi Kesehatan Mental dan Sikap Komunitas sebagai Prediktor Pencarian Pertolongan Formal. Jurnal Psikologi, 44(1), 50. https://doi.org/10.22146/jpsi.22988

Cucun Sunaengsih. (2016). Pengaruh Media Pembelajaran terhadap Mutu Pembelajaran Pada Sekolah Dasar Terakreditasi A. Jurnal Mimbar Sekolah Dasar, 3(2), 183-190.

https://doi.org/10.17509/mimbar-sd.v3i2.4259

Dawam Mahfud, Mahmudah, W. W. (2015). Pengaruh Ketaatan Beribadah Terhadap Kesehatan Mental Mahasiswa Uin Walisongo Semarang. JURNAL ILMU DAKWAH, 35(1), 35-51.

Edi Kuswadi. (2019). Peran Lingkungan Sekolah dalam Pengembangan Mental Siswa. EL-BANAT: Jurnal Pemikiran Dan Pendidikan Islam, 9(1), 62-78.

Fattah Hanurawan. (2012). Strategi Pengembangan Kesehatan Mental Di Lingkungan Sekolah. PSIKOPEDAGOGIA: Jurnal Bimbingan Dan Konseling, 1(1), 1-9.

https://doi.org/10.12928/psikopedagogia.v1i1.2572

Faulina Sundari. (2017). Peran Guru Sebagai Pembelajar Dalam Memotivasi Peserta Didik Usia SD. Prosiding Diskusi Panel Pendidikan "Menjadi Guru Pembelajar," 144-146. 
Firmasyah, M. (2017). Pengaruh Pertumbuhan Perusahaan, Total Asset Turnover, Return on Investment, Earning Per Share Terhadap Harga Saham (Studi Perusahaah Manufaktur Di Bei). AJIE - Asian Journal of Innovation and Entrepreneurship, $2(2)$ 110-121. https://doi.org/10.20885/ajie.vol2.iss2.art3

Ghozali Rusyid Affandi, D. R. D. (2011). Religiusitas Sebagai Prediktor terhadap Kesehatan Mental Studi terhadap Pemeluk Agama Islam. Jurnal Psikologi, 6(1), 147-173.

Haris Munandar. (2018). Pola Pembinaan Keagamaan di SMA Plus Boarding School Astha Hannas Subang. Jurnal Tarbiyah, 25(1), 20-39. https://doi.org/10.30829/tar.v25i1.233

Istiqomah. (2018). Upaya Guru Meningkatkan Motivasi Belajar Siswa Min Pemurus Dalam Kecamatan Banjarmasin Selatan. TARBIYAH ISLAMIYAH, 8(1), 12-17.

Iwan Setiawan, Andewi Suhartini, B. S. A. (2020). Implementasi Pengembangan Keberagamaan Peserta Didik di Sma Muahammadiyah Cipanas dan Pengaruhnya Terhadap Pembentukan Karakter. Edukasi Islami: Jurnal Pendidikan Islam, 09(01), 21-32.

Jumhuri, M. A. al. (2016). Pembinaan Moral Spiritual Siswa Melalui Pembiasaan Shalat Jamaah (Studi Analisis Siswa Madrasah Tsanawiyah NW Putra Narmada). Jurnal Al-Amin: Kajian Pendidikan Dan Sosial Kemasyarakatan, 1(1), 72-116.

Kamra, Y. (2019). Pelaksanaan Kegiatan Ekstrakurikuler Dalam Upaya Mengembangkan Lingkungan Pendidikan yang Religius di SMP N 13 Kota Bengkulu. Al-Bahtsu, 4(2), 158-165.

Kenny Dewi Fhadila. (2017). Menyikapi Perubahan Perilaku Remaja. Jurnal Penelitian Guru Indonesia, $2(2)$ $17-23$. https://jurnal.iicet.org/index.php/jpgi/article/view/220

Layla Takhfa Lubis, Laras Sati, Naura Najla Adhinda, Hera Yulianirta, B. H. (2019). Peningkatan Kesehatan Mental Anak dan Remaja Melalui Ibadah Keislaman. Al-Hikmah: Jurnal Agama Dan Ilmu Pengetahuan, 16(2), 120-129. https://doi.org/10.25299/jaip.2019.vol16(2).3898

Lina Hadiawati. (2008). Pembinaan Keagamaan sebagai Upaya Meningkatkan Kesadaran Siswa Melaksanakan Ibadah Shalat (Penelitian di kelas X dan XI SMK Plus Qurrota Ayun Kecamatan Samarang Kabupaten Garut. Jurnal Pendidikan Universitas Garut, 2(1), 18-25.

Maryamah, E. S. dan. (2013). Pembinaan Keberagamaan Siswa Melalui Pengembangan Budaya Agama di SMA Negeri 16 Palembang. Ta'dib, 18(02), 169-214.

Massuhartono, M. (2018). Psikologi Islam, Terapi Religi Melalui Dzikir Pada Penderita Gangguan Jiwa. JIGC, 2(2), 201-214.
Moh Ahsanulkhaq. (2019). Membentuk Karakter Religius Peserta Didik Melalui Metode Pembiasaan. Jurnal Prakarsa Paedagogia, 2(1), 21-33.

Muhammad Nur Hakim. (2018). Upaya Kepala Madrasah Dalam Membina Budaya Religius. IMProvement, 5(1), 74-88. https://doi.org/10.21009/Improvement.051.07

Nurhayati. (2015). Pengaruh Sikap dan Kebiasaan terhadap Hasil Belajar Matematika. Formatif: Jurnal Ilmiah Pendidikan MIPA, 1(3), 247-254. https://doi.org/10.30998/formatif.v1i3.77

Reza, I. F. (2016). Efektivitas Pelaksanaan Ibadah Dalam Upaya Mencapai Kesehatan Mental. Psikis: Jurnal Psikologi Islami, 1(1), 105-115.

Samsurijal. (2019). Pembinaan Keagamaan Peserta Didik Melalui Kegiatan Ekstrakulikuler di Madrasah Ibtidaiyyah As'Adiyah Banua Baru. Inspiratif Pendidikan, 8(1), 114-125. https://doi.org/10.24252/ip.v8i1.7841

Sariah. (2015). Pola Pembinaan Keagamaan Pada Siswa Sekolah Luar Biasa Pelita Hati Pekanbaru. POTENSIA: Jurnal Kependidikan Islam, 14(2), 245-262.

Tamama Rafiqah. (2016). Upaya Mengatasi Gangguan Mental Melalui Terapi Zikir. Jurnal Dimensi, 4(3), 1-22. https://doi.org/10.33373/dms.v4i3.48

Ulin Nihaya. (2016). Peran Komunikasi Interpersonal untuk Mewujudkan Kesehatan Mental Bagi Konseli. Islamic Communication Journal, 1(1), 30-42. https://doi.org/10.21580/icj.2016.1.1.1244

Yunita Latifah, Agus Fakhruddin, E. S. (2015). Pembinaan Keagamaan Siswa Smp Di Pondok Pesantren Daarut Tauhiid Bandung. TARBAWY: Indonesian Journal of Islamic Education, $\quad 2(2), \quad 137$. https://doi.org/10.17509/t.v2i2.3451

Zulkarnain. (2019). Kesehatan dan Mental dan Kebahagiaan: Tinjauan Psikologi Islam Zulkarnain. Mawa'izh: Jurnal Dakwah Dan Pengembangan Sosial Kemanusiaan, 10(1), 18-38. 